ROSJA: AZJA CZY EUROPA?

ROZWAŻANIA O ŚWIADOMOŚCI

INTELIGENCJI POLSKIEJ XIX WIEKU

JAKO KONTEKŚCIE IDEOWYM TWÓRCZOŚCI CYPRIANA NORWIDA

Rosja już z geograficznego punktu widzenia położona jest niejednoznacznie i wzbudza wątpliwości co do przynależności do kontynentu europejskiego. Europa jest jednak nie tylko nazwą geograficzną, służącą określeniu jednej z części ziemi, ale także tworem kulturowym i cywilizacyjnym. Pod tym względem europejska przynależność Rosji wzbudzała jeszcze większe kontrowersje. Problem ten dostrzegali historycy badający dzieje Europy. Norman Davies zauważał: „Przez ponad 500 lat zasadniczą trudnością w próbach definiowania Europy był brak odpowiedzi na pytanie, czy należy do niej włączyć Rosję, czy nie" ${ }^{\text {. Gerard }}$ Delanty stwierdzał, że na zachodzie Europy Rosja uważana była za „,przedłużenie Azji” ". Problem europejskości Rosji obecny był w jeszcze większym stopniu w polskim XIX-wiecznym dyskursie. Tym bardziej że relacje z Rosją należały ówcześnie do dość skomplikowanych, co czyniło tę kwestię jeszcze bardziej ważką i aktualną. Na problematyczność europejskości Rosji zwracał uwagę polski poeta i geograf Wincenty Pol w jednej ze swoich prac zatytułowanej Historyczny obszar Polski:

[...] Europa w tym chaosie politycznym nie może dojść: gdzie jej wschodnie leżą granice? Czy Rosja należy do Europy? Czy ma w niej Europa widzieć tylko przednią straż Azji? Europa nie wie, czy ma się emancypować spod azjatyckich wpływów Rosji, czy cywilizować

\footnotetext{
${ }^{1}$ N. DAVIES, Europa - rozprawa historyka z historia, przeł. E. Tabakowska, Kraków 2010, s. 35.

${ }^{2}$ G. DELANTY, Odkrywanie Europy. Idea, tożsamość, rzeczywistość, przeł. R. Włodek, Warszawa-Kraków 1999, s. 67.
} 
Rosję, żeby się stała europejską? Nie wie, czy ma w carze rosyjskim uznawać sprzymierzeńca, czy pana? Czy potęgę europejską, czy azjatyckiego najeźdźcę?? ${ }^{3}$

Zastanawiając się nad kwestią europejskości bądź azjatyckości Rosji w świadomości polskiego społeczeństwa XIX-wiecznego, trzeba wziąć pod uwagę kilka różnych aspektów tego problemu. $Z$ jednej strony kwestia ta bywała poruszana w naukowych dyskusjach dotyczących narodowościowej przynależności Rosjan, z drugiej istniało również potoczne wyobrażenie o przynależności Rosjan do obcej kultury, niemotywowane w sposób naukowy, ale wynikające raczej z przekonania o niższości kulturowej Rosjan, uznawaniu ich za barbarzyńców.

Na początek warto na moment zatrzymać się nad aspektem geograficznym i przyjrzeć wschodniej granicy Europy. Aspektu geograficznego nie należy lekceważyć, gdyż, jak przekonywał Wincenty Pol, bywał on wykorzystywany również w „,polityce praktycznej” ${ }^{4}$. Analizując dziewiętnastowieczne podręczniki szkolne do geografii, encyklopedie czy mapy, można zauważyć, że wschodnia granica Europy już wtedy najczęściej wytyczana była wzdłuż pasma gór Ural, co oznaczałoby, że chociaż w części Rosja przynależeć miała do Europy. Nie było to jednak regułą. Ludwik Pietrusiński w Podróżach, przejażḋ̇kach i przechadzkach po Europie zauważał, że: „dotychczas o granicę Europy z Azją spierają się geografowie" ${ }^{\circ}$. Koncepcji granicy na Uralu przeciwstawiał się m.in. Wincenty Pol. Uważał, że przesunięcie europejskiej granicy na Ural (co skutkowało narodzeniem pojęcia „europejskiej Rosji”) było efektem teorii stworzonej przez geografów niemieckich. Zdaniem polskiego poety i geografa fakty przeczyły jednak tym teoriom i prowadziły do zupełnie odmiennych wniosków m.in.:

3. Że granica Europy od wschodu nie leży nad Uralem i Kaukazem, lecz kończy się za obszarem wodnym Dźwiny i Dniepru.

4. Że obszar Wołgi należy do środkowej Azji zamkniętej, która się za biegiem wód nie łączy z otwartymi morzami na globie - i że tym mniej można Europie kłaść za granice Ural i Kaukaz, których nikt przecież do Europy nie policzył, co wie, że indywidualność narodowa i cywilizacja chrześcijańska jest cechą europejskich narodów ${ }^{6}$.

\footnotetext{
${ }^{3}$ W. Pol, Historyczny obszar Polski, [w:] TENŻE, Dzieła proza, t. V, Lwów 1878, s. 7.

${ }^{4}$ Tamże, s. 8.

${ }^{5}$ L. PIETRUSIŃSKI, Podróże, przejażdżki i przechadzki po Europie, t. I, Warszawa 1843, s. 385.

${ }^{6}$ W. PoL, Historyczny obszar, s. 8.
} 
Pol, jak widać, nie poprzestawał na argumentach czysto geograficznych, ale sięgał również po argumenty natury kulturowej oraz religijnej. W dalszej części swojej rozprawy wprost pisał o tym, że Rosja pozostawała Europie obca. Oto niektóre z wysuwanych przez poetę-geografa argumentów:

Wszystko też na pozór europejski jest w społeczeństwie moskiewskim rzeczywiście azjatyckim. Na każdą idę̨ europejską rzucają się nieprzyjaźnie Moskale jak wilcy na łup. Żadna instytucja europejska nie może się u nich przyjąć ani zaaklimatyzować ${ }^{7}$.

Tradycje azjatyckie nieznane w Europie - tradycje Atylli, Tamerlana, Batu-Chana są jedyną tradycją historyczną Moskwy, która od Nogajca wzięła nahaj, od Kałmuka konia, od Czuda morze, z Bizancjum przewrotność, z Niemiec kij kapralski i dyplomację, a od Chińczyka rachunek na szczoty, którego umiejętność zamieniła cały lud moskiewski w kupca lądowych karawan $[\ldots]^{8}$.

Wszystkie europejskie narody, od Hiszpanii po Polskę, żyły w przeciągu ery chrześcijańskiej wspólnym zżyciem jedności kościoła, światła, obyczajów i cywilizacji chrześcijańskiej, nabytkiem wynalazków i postępowych idei wieku. Jedna Moskwa nie wniosła nic do tej skarbnicy; nie dała Europie ani jednej idei, ani jednego wielkiego człowieka, który by na pożytek ludzkości pracował $[\ldots]^{9}$.

Pol jako geograf spoglądał jednak na kwestię europejskości Rosji w sposób wyraźnie pogłębiony. W utworach literackich innych autorów rzadziej wdawano się w dyskusje na temat przebiegu granicy wschodniej i za granicę Europy, tak jak chciały tego podręczniki, uważano najczęściej Ural.

Kwestia europejskiej bądź azjatyckiej przynależności Rosji jeszcze bardziej komplikowała się, kiedy pod uwagę brano argumenty dotyczące pochodzenia Rosjan. Od dawna zwykło uważać się Rosjan za Słowian. Na początku XIX w. popularna była nawet koncepcja panslawizmu, czyli politycznego zjednoczenia wszystkich Słowian pod berłem rosyjskim (gdyż Rosja była uważana za najsilniejsze w owym czasie z państw słowiańskich, jedyne cieszące się pełną wolnością). W Polsce propozycja ta nie wzbudzała szczególnego entuzjazmu właśnie ze względu na dominującą rolę Rosji, ale również tutaj znalazła swoich zwolenników, do których należeli m.in. hrabia Henryk Rzewuski i Adam Gurowski. Warto wspomnieć też Henryka Kamieńskiego, autora dzieła Rosja i Europa

\footnotetext{
${ }^{7}$ Tamże, s. 20

${ }^{8}$ Tamże, s. 21.

${ }^{9}$ Tamże.
} 
(dzieła, z którym zapoznał się także Cyprian Norwid ${ }^{10}$ ). Co prawda nie popierał on działań i wystąpień wspomnianych wcześniej autorów, ale sam również twierdził, iż Polska powinna sprzymierzyć się z Rosją. Stawiał jednak inne zasady tego przymierza. Niezależnie od tego, warto przyjrzeć się zapatrywaniom Kamieńskiego na kwestię rosyjską. Podkreślał on problemy, jakie wynikały z niepojęcia Rosji. Rosja - w jego mniemaniu - była bowiem ,zagadką dla całej Europy”" . Według jego definicji Rosja „to kraj niepodobny do żadnego innego, każda rzecz staje się czym innym niżby gdziekolwiek indziej była" ${ }^{\prime 2}$. W innym miejscu stwierdzał zaś, iż ani Rosji, ani Moskali nie można sądzić „,na skalę europejską”, gdyż „znajdujemy i w państwie, i w narodzie coś zupełnie odmiennego" ${ }^{\text {"13 }}$. Rosja była więc według Kamieńskiego czymś odrębnym od Europy, stanowiła osobny świat. Jedynie skazana na jej sąsiedztwo Polska była w stanie pośredniczyć w jej kontaktach z Europą, ułatwić Europie zrozumienie Rosji. Także ta koncepcja spotkała się jednak z ostrą krytyką. Dionizja Poniatowska w opublikowanej anonimowo rozprawie Panslawizm i Polska nazwała „systemat panslawizmu” Kamieńskiego „niedorzecznym” ${ }^{14}$. Z rozprawą Poniatowskiej polemizował z kolei Cyprian Norwid ${ }^{15}$.

Polscy twórcy w idei panslawizmu najczęściej dopatrywali się więc zagrożenia. Zastrzeżenia co do niektórych wzbudzała jednak już kwestia słowiańskości Rosji. W latach 60. XIX w. w dyskusji pojawiły się głosy o niesłowiańskim pochodzeniu Rosjan, którym zarzucano teraz, że jedynie podszywali się pod Słowian. W zamian przypisywano im tatarskie, a więc azjatyckie korzenie. Za twórcę tej teorii uważany jest Franciszek Henryk Duchiński, który w sposób naukowy próbował dowodzić niesłowiańskości Rosjan. Kwestii tej poświęcił obszerne rozprawy ${ }^{16}$, wygłaszał również wykłady w Cercle des Sociétés Savantes. Dowodził w nich, że Rosjanie ani z ducha, ani z języka, ani z pochodzenia, ani też

\footnotetext{
${ }^{10}$ Norwid wspominał o książce Rosja i Europa w liście do Józefa Bohdana Zaleskiego z 16 lipca 1857 r. Zob. C.K. NorWID, Do Józefa Bohdana Zaleskiego, [w:] TENŻE, Pisma wszystkie, zebrał, tekst ustalił, wstępem i uwagami krytycznymi opatrzył J.W. Gomulicki, t. VIII, Warszawa 1971, s. 310.

${ }^{11}$ H. KAMIEŃSKI, Rosja i Europa: Polska, Paryż 1857, s. XLV.

${ }^{12}$ Tamże, s. XLV.

${ }^{13}$ Tamże, s. 4.

${ }^{14}$ [D. PoniatowsKa], Panslawizm i Polska, Poznań 1857, s. 20.

${ }^{15}$ C. K. NoRwID, O broszurze „Polska i panslawizm”, PWsz, VII, 187-189.

${ }^{16}$ Zob. F.H. DuCHIŃSKI, Galeria obrazów polskich. Oddział 1, Różnice ludów indoeuropejskich a turańskich pod względem fizjonomii i odzieży, Paryż 1863; Pisma Franciszka Duchińskiego, t. I-III, Rappersvil 1901-1904.
} 
z charakteru nie należeli do Słowian. Mocno eksponował natomiast ich mongolskie, fińskie i uralskie korzenie. W tekście Do Rządu Narodowego powstańczego pisat:

Moskale byli i są obcy Słowianom i wszystkim ludom indoeuropejskim, i z potrzeb swych wynikających $\mathrm{z}$ pochodzenia, i z potrzeb swych wynikających z charakterów cywilizacji - i, na ostatek, co najważniejsza, i z potrzeb swych wynikających ze stosunków historycznych; bo Moskale są ściślej połączeni stosunkami historycznymi z Turkami średniej Azji, których są częścią nieoddzielną i z krwi, i z pochodzenia, i z charakterów cywilizacji, aniżeli z najbliższymi swymi sąsiadami Słowianami znad Dźwiny i znad Dniepru ${ }^{17}$.

Odnosił się również do argumentów natury geograficznej, stwierdzając tym razem, że „samą budową ziemi złączył Pan Bóg Moskwę z najgłębszą Azją,"18. Wyraźnie rozgraniczał też Rosjan, których postulował nazywać Moskalami, od Rusinów zamieszkujących ziemie naddnieprskie i naddniestrzańskie. Historyk w swoich pracach przestrzegał również przed polityką historyczną prowadzoną przez Rosję. Uważał, że podszywając się pod Słowian, Moskale chcą ukazać swoje prawo do rządzenia pozostałymi narodami słowiańskimi.

Na koncepcję Duchińskiego powoływał się Ferdynand Władysław Czaplicki, autor Czarnej księgi, który argumentował nią posługiwanie się określeniami „Moskwa, Moskal” zamiast „Rosja, Rosjanin”.19. Zbliżone poglądy prezentował również galicyjski działacz polityczny, ks. Wojciech Michna, który w pracy pt. Pogląd na wschodnia Europe $i$ Azję $i$ wyjaśnienie stosunków, jakie miała Moskwa z ludami sławiańskiemi od pierwocia bytu do czasów naszych wyraźnie odróżniał pojęcia Rosji i Moskwy od Rusi. Według jego wywodów Moskwa miała fiński, a więc azjatycki rodowód. Autor posługiwał się argumentami odnoszącymi się do pochodzenia Rosjan (wywodził je od ludów fińskich i uralskich), nazewnictwa (nazwa Moskwa miała wywodzić się z języka fińskiego), wiary (wskazywał na silne związki z ,mahometanizmem”), języka (rodzimy język miał wywodzić się z fińskiego, język znany jako rosyjski powstał zaś na skutek kontaktów ze Słowianami). Poglądy, jakie prezentował w swojej rozprawie, dobrze streszcza poniższy fragment:

Rosja to jedna część chrześcijanina, a trzy części Mongoła, ma ubiór i wiarę Europy a ducha Azji! U Sławian jest życie Europy a w Rosji życie Azji. Słowianie poszli za Chrystusem,

\footnotetext{
${ }^{17}$ TENŻE, Do Rządu Narodowego powstańczego, tamże, t. III, s. 287.

${ }^{18}$ Pisma Franciszka Duchińskiego, t. II, s. 10.

${ }^{19}$ F.W. CzAPLICKI, Czarna księga: 1863-1868, Kraków 1869, s. 2.
} 
a Rosja poszła krzywo i jest cywilizacji słowiańskiej obcą jako obce plemię fińskie, jako obcy duch uralski ${ }^{20}$.

O podszywaniu się Rosjan pod słowiańskość wspominał również Ernest Buława (właśc. Władysław Tarnowski), który we wstępie do tomu swoich poezji (wyd. 1865 r.) pisał o carze Mikołaju I, że to: „car nie słowiańskiej, lecz tatarskiej hordy, która pod słowiańskość się podszyła”21. Niepewność w tej sprawie wykazywał również Józef Ignacy Kraszewski, choć ostatecznie uznał kwestię za drugorzędną, jak pisał w Rachunkach: „Czy Moskale są Słowianami, czy osłowianieni (jak opolaczeni) turanie, nam to wszystko jedno, byle nie byli zwierzętami",22. Wyraźny podział na pokolenia słowiańskie i turańskie przedstawiony został również na mapce Granice między narodami Arja-Europejskimi $i$ Turano-Moskiewskimi znajdującej się w zbiorach Biblioteki Narodowej, a datowanej na 1863 r. Po stronie Arja-Europejskiej znalazły się miasta tj. Charków, Kijów, Smoleńsk, Nowogród czy Psków, natomiast po stronie turańskiej Moskwa, Kursk, Kaługa, Wiaźma, Biełozersk, najprawdopodobniej również Petersburg itd. $^{23}$

Teorie o azjatyckim pochodzeniu Słowian najwyraźniej były więc obecne w świadomości polskiego społeczeństwa. Warto w tym miejscu zwrócić jednak uwagę, że szczególne nasilenie tego typu koncepcji nastąpiło w latach 60., a więc $\mathrm{w}$ okresie po powstaniu styczniowym, co związane było zapewne $\mathrm{z}$ nasileniem niechęci wobec Rosjan. Co prawda również wcześniej można w badanej literaturze odnaleźć liczne przykłady określania Rosjan mianem Azjatów czy Mongołów, jednak miały one odmienny charakter. Nie wynikały z przekonania o rzeczywistym pochodzeniu Rosjan, ale z aspektów kulturowych i cywilizacyjnych.

Powróćmy jednak do Duchińskiego, gdyż jego koncepcje były dobrze znane również Cyprianowi Norwidowi, który słuchał wygłaszanych przez historyka prelekcji w Cercle des Sociétés Savantes. W swoich listach poeta kilkakrotnie polemizował $\mathrm{z}$ teoriami przedstawianymi przez Duchińskiego. Z dystansem odnosił się do azjatyckiej koncepcji Rosji, a nawet wprost ją krytykował. Trzeba jednak podkreślić, że nie było to jednoznaczne $\mathrm{z}$ afirmacją Rosji i jej polityki.

${ }^{20}$ W. MichnA, Pogląd na wschodniq Europę i Azją i wyjaśnienie stosunków, jakie miata Moskwa z ludami sławiańskiemi od pierwocia bytu do czasów naszych, Przemyśl 1864, s. 39-40.

${ }^{21}$ E. BuŁaWA, Krople czary. Poezje, Drezno 1865, s. 9.

22 J.I. KRASZEWSKI, Rachunki: (pt.1-2). z roku 1867 (rok drugi), Poznań 1868, s. 165.

${ }^{23}$ Granice między narodami Aria-Europejskimi i Turano-Moskiewskimi, [b.m.] 1863. 
Poeta dostrzegał płynące z jej strony niebezpieczeństwo, tylko że szukał innych dróg na jego zaniechanie. Taką drogą nie było - jego zdaniem - odepchnięcie Rosji od Europy i skierowanie w stronę Azji. Norwid uważał, że mogłoby to przynieść zupełnie odwrotny skutek i doprowadzić do sprzymierzeniem się Rosjan z jeszcze bardziej barbarzyńskimi i licznymi Chińczykami, co stwarzałoby bardzo realne zagrożenie dla Europy. Przyznawał w tym rację niepopularnemu w Królestwie Polskim Aleksandrowi Wielopolskiemu. Jak pisał:

Następnie - Wielopolski ma jeszcze tę prawdę, że TRZEBA ROSJI ZOSTAWIĆ NIECO EUROPEJSKIEGO CHARAKTERU: odepchnąć ją od Azji jest to zrobić ją czołem miliona Chińczyków, którzy zaleją świat [...]. Oto, czego patrioci polscy nie chcą wiedzieć - tak iż gdyby się nie zostawiło niejakiej europejskości Rosji, to trzeba by na drugi dzień po zwycięstwie nad Moskalami w ten moment przygotować się do możności wystawienia 300000 armii i potężnego skarbu - i rozpoczęcia walki z milionami, osłaniając Europę, przedającą armaty, koleje żelazne i pancerne statki każdemu z barbarzyńców, który więcej zapłaci ${ }^{24}$.

Zdaniem poety trudne relacje z Rosją należało rozwiązywać $\mathrm{w}$ inny sposób niż poprzez obrażanie się na Rosję i uznawanie jej za kraj azjatycki i barbarzyński. W liście do Karola Rupretcha zauważał, że właściwym rozwiązaniem byłoby posiadanie w Rosji partii ${ }^{25}$.

Jak już zauważono na początu, powodem, dla którego Rosję często wyłączano z obrębu Europy, były kwestie cywilizacyjne, kulturowe i religijne. Dostrzegano inność Rosji, jej odrębne zwyczaje, kulturę, różny od europejskiego system wartości. Źródeł cywilizacji rosyjskiej doszukiwano się raczej w Azji niż w Europie. Nie chodzi tutaj jedynie o kwestię pochodzenia, ale o zwyczaje, kulturę, które miały być odrębne od tych europejskich. Choć dostrzegano próby dostosowywania się Rosji do Europy, polscy pisarze często uważali te próby za nieudane. Niektórzy sugerowali nawet, że Rosja posiada dwa oblicza, jedno europejskie, cywilizowane na użytek Europy i drugie, prawdziwe - dzikie, barbarzyńskie, daleko odbiegające od europejskich standardów. Polscy pisarze twierdzili niejednokrotnie, że Europa ulegała temu złudzeniu, wierzyła w cywilizację Rosji, nie chciała zaś uwierzyć przestrogom czynionym przez lepiej zapoznaną z Rosją Polskę. Według Józefa Ignacego Kraszewskiego cywilizacja w Rosji „Była [...] i jest formalną, powierzchowną, empiryczną; była i jest rodzajem przyjętego języka, którym się rozmawia z Europą, ale się go nie używa w domu” ${ }^{26}$, nieco dalej dodawał „cywilizacja zaledwie zafarbowała skórę, w krew

\footnotetext{
${ }^{24}$ C.K. NORWID, Philoctet, PWsz VII, 129-130.

${ }^{25}$ TENŻE, Do Karola Ruprechta, PWsz IX, 107.

${ }^{26}$ J.I. KRASZEWSKI, Rachunki, s. 67.
} 
i soki nie przeszła" ${ }^{27}$. Charakteryzujący Rosję despotyzm miał - zdaniem pisarza - strzec Rosji od granic Europy. W cytowanym tekście pojawiły się nawet słowa o rzekomej nienawiści Rosji do wszystkiego co europejskie. Przytoczone zostały również słowa przypisywane przez Kraszewskiego rosyjskiemu filozofowi Aleksandrowi Hercenowi:

Wypędzają nas z Europy jak Bóg z raju Adama. - Ale czyście też pewni, że my Europę za raj mamy? A tytuł Europejczyka za wielce honorowy? Jest gruba omyłka w czasie. - Nie wstydzimy się być Azjatami i nie potrzebujemy anektować się do nikogo ani na prawo, ani na lewo. My sami sobie starczym, jesteśmy częścią świata między Ameryką a Europą - na tym nam dosyć ${ }^{28}$.

O specyficznym stosunku Rosjan do Europy pisał też Kraszewski w powieści Moskal. Typowy Rosjanin, czy, jak określa go pisarz, Moskal „W Europie gra rolę cywilizowanego, w domu wraca do barbarzyństwa, liberalny w słowach, w czynach jest istotą służebną, śpiewa po cichu piosenki rewolucyjne, ale na zawołanie staje w szeregu obrońców Cara" ${ }^{29}$.W innym miejscu pisał również: „Jakkolwiek Moskale dumni są ze swego kraju i cywilizacji, czują oni mimowolnie, jadąc na zachód, że się do Europy zbliżają $[\ldots]^{30}$. Sama Rosja najwyraźniej nie była więc jeszcze częścią Europy.

Na problem Rosji z określeniem własnej tożsamości zwracał uwagę również autor komentarza do przywoływanej już mapki z 1863 r., który twierdził, że „przyczyna nieświadomości stosunku Słowian do Moskali zamyka się w fałszowaniu tychże z przyczyn politycznych"31. Podkreślał również zmienność polityki rosyjskiej w tej kwestii. Jak twierdził: „Był czas, że Moskale wywodzili się od Mongołów i szczycili się tym" ${ }^{\text {,32 }}$. Takim miał być czas panowania cara Iwana Groźnego. Zmiany nastąpiły, w mniemaniu autora, w okresie panowania cara Piotra I, który „chciał moskali poeuropejczyć” ${ }^{33}$. Jego córka Elżbieta „,W przekonanie chciała wprowadzić, że Moskale należą do Europy"34, co skutkowało represjami na tych, którzy mieli odmienną opinię na ten temat. Katarzyna II miała

\footnotetext{
${ }^{27}$ Tamże, s. 68

${ }^{28}$ Tamże, s. 163.

${ }^{29}$ TENŻE, Moskal. Obrazek współczesny, Lipsk 1865, s. 5.

${ }^{30}$ Tamże, s. 49.

${ }^{31}$ Granice między narodami.

${ }^{32}$ Tamże.

${ }^{33}$ Tamże.

${ }^{34}$ Tamże.
} 
nawet wydać ukaz, że „Moskale są Europejczycy” ${ }^{35}$. W ostatnim czasie modne stało się zaś wywodzenie Moskali ze Słowiańszczyzny ${ }^{36}$.

Działania Rosjan mające na celu przekonanie Europy o ich cywilizacji i europejskości polskim autorom nie wydawały się przekonujące. Większą siłę przebicia niż carskie ukazy miały tu bowiem własne doświadczenia narodu, a te, częściej niż o cywilizacji Rosjan, świadczyły o ich barbarzyństwie. Toteż polscy autorzy niejednokrotnie podejmowali działania skrajnie odwrotne, mające na celu odkłamanie rosyjskiego przekazu, zrzucenie z Rosji maski cywilizowanego kraju, uświadomienie Europie niebezpieczeństwa, jakie Rosja niesie za sobą.

Próbując budować antagonizm europejsko-rosyjski (na wzór antagonizmu polsko-rosyjskiego), polscy autorzy podkreślali rolę Polski jako strażniczki Europy, jej osłony przed barbarzyńskimi, mongolskimi zapędami Rosji. Próbowali też ukazać niebezpieczeństwo, na jakie narażona była Europa pozbawiona tego buforu bezpieczeństwa. Polska była więc, w ich mniemaniu, sferą graniczną, oddzielającą to, co europejskie, od azjatyckiego. Rosja zepchnięta została do Azji. Tego typu schematy myślowe często powtarzały się w liryce czasów walk polsko-rosyjskich, a także w publicystyce.

O zagrożeniu Europy ze strony Rosji mowa jest m.in. w wierszu Maurycego Gosławskiego Do Europy. Podmiot liryczny ostrzega bierną, przyglądającą się losom Polski, Europę przed niebezpieczeństwem:

\author{
Znieważona i okuta, \\ Drżąc, wyglądasz sensu dnia; \\ Czekaj, nim ci ciężar knuta \\ W dzikiej dłoni Tamerlana \\ Padającej na kolana \\ Przeznaczenie nowe $\mathrm{da}^{37}$.
}

\footnotetext{
${ }^{35}$ Tamże.

${ }^{36}$ Tytułem dopowiedzenia warto przypomnieć, za Oskarem Haleckim, o trzech typach podejścia Rosjan do kwestii jej przynależności: okcydentalistycznym, słowianofilskim oraz euroazjatyckim. Tylko zwolennicy pierwszego podejścia uważali Rosję za pełnoprawną, lecz nieco zapóźnioną część europejskiej cywilizacji. Słowianofile często podkreślali natomiast odrębność i wyższość Słowiańszczyzny od zachodniej Europy, którą postrzegali jako zepsutą. Zwolennicy ostatniej z koncepcji mieli uważać Rosję za osobną część świata leżącą między Azją a Europą. Zob. O. HALECKI, Historia Europy - jej granice i podziały, przeł. J.M. Kłoczowski, Lublin 2000, s. 90-92.

${ }^{37}$ M. GosŁawski, Do Europy, [w:] Zbiór poetów polskich XIX w., ułożył i oprac. P. Hertz, Księga druga, Warszawa 1959, s. 121.
} 
„Ciężar knuta” oraz „dzika dłoń Tamerlana” oznaczają tutaj niewątpliwie niosącą Europie zagrożenie Rosję. Dodatkowo sugerują powinowactwa Rosji z Azją (Tamerlan był słynącym z okrucieństwa władcą mongolskim, który w XIV w. podbił większą część Azji Środkowej; kojarzony także często z carską Rosją knut bywał uważany za pozostałość po latach tatarskiej niewoli). Podmiot liryczny nawiązuje przez to do azjatyckiego charakteru Rosjan. Wciąż nie chodziło jednak o ich pochodzenie, ale raczej o swoistą, zupełnie różną od europejskiej mentalność ukształtowaną pod wpływem tatarskich najeźdźców.

Azjatycka natura Rosjan jeszcze mocniej została wyeksponowana w jednej ze strof Pieśni strzelców Władysława Ludwika Anczyca z tomu Pieśni zbudzonych (1863 r.). Rosjanie wprost zostali tutaj sklasyfikowani jako wróg - „potomek Dżengishana" (władcy mongolskiego panującego na przełomie XII i XIII w.), a jako właściwe im miejsce wskazana została Azja:

Do Azji precz, potomku Dżengishana,

Tam naród twój, tam ziemia carskich gal

$[\ldots]$

Do Azji precz tyranie, tam siej mordy,

Tam ziemia twa, tam panuj, tam twa śmierć;

Tu Polska jest, tu zginiesz i twe hordy,

Lud naród w pień wymorduj, wysiecz, zgnieć $[\ldots]^{38}$.

Tutaj w przeciwieństwie do poprzedniego utworu pojawiało się już wskazanie na kwestię genealogiczną. Rosyjski wróg nazwany zostaje wszak potomkiem mongolskiego wodza. Azjatyckość nie jest tylko cechą nabytą, ale dziedzictwem Rosjan.

Także w dzienniku „Niepodległość”, ukazującym się w trakcie powstania styczniowego, Polska i Moskwa przedstawione zostały jako dwie nienawistne potęgi. Polska miała stać na „przedniej straży Europy”, 39 , Moskwa zaś „na czele wydziedziczonych z cywilizacji hord azjatyckich" ${ }^{40}$. Moskwa określana była jako gwóźdź w ciele Europy lub jako zwisająca nad nią klątwa ${ }^{41}$. Metafory te wskazują na wyraźną obcość Rosji i jej odrzucenie poza obręb Europy. Jedno-

\footnotetext{
${ }^{38}$ W.L. ANCZYC, Pieśń strzelców, [w:] Władysław Ludwik Anczyc: życie i pisma, oprac. M. Szyjkowski, t. II: Wiersze i poemata, Kraków 1909, s. 88.

39 „Niepodległość” 1863, nr 4, s. 1.

${ }^{40}$ Tamże.

${ }^{41}$ Tamże.
} 
cześnie redaktorzy pisma stwierdzali, że Moskwa, owszem, weszła w skład państw europejskich, ale weszła do niego przez gwałt na Polsce ${ }^{42}$.

W twórczości Norwida brakuje tak wyraźnych deklaracji. Nawet w utworach powstałych pod wpływem powstania styczniowego poeta dystansował się od kreowania obrazu Rosjan poprzez odniesienie do ich azjatyckiej natury. Pozostawał wciąż wierny twierdzeniu, że „Rosjanie są tacyż sami Słowianie jak Polacy - tamci z azjatyckimi, ci z europejskimi ludami pomieszani: bo tak być powinno!...."43.

Podsumowując, można zauważyć, że pod wpływem wydarzeń politycznych zrodziła się tendencja do ukazywania Rosji jako krainy azjatyckiej, Polski zaś jako przedmurza stojącego na straży Europy. Norwid nie był zwolennikiem tej tezy. Poeta dobrze zdawał sobie sprawę $\mathrm{z}$ odmiennej natury Rosjan. Jednocześnie jednak nie raz w swoich tekstach krytycznie odnosił się do wiązania Rosji $\mathrm{z}$ azjatyckością, gdyż mogło ono przynieść więcej zła niż korzyści. Warto w tym miejscu przytoczyć słowa Mieczysława Inglota, które, jak się wydaje, ujmują sedno rzeczy: „Tymczasem w wywodach Norwida Rosja była ujmowana jako arena walki pierwiastków europejskich i azjatyckich. W interesie Europy leżało zeuropeizowanie Rosji, a realizacji tego zadania miała się podjąć w pierwszej kolejności Polska" ${ }^{44}$.

\section{BIBLIOGRAFIA}

„Niepodległość” 1863.

BuŁawa E., Krople czary. Poezje, Drezno 1865.

CZAPLICKi F.W., Czarna księga: 1863-1868, Kraków 1869.

DAVIES N., Europa - rozprawa historyka z historia, przeł. E. Tabakowska, Kraków 2010.

Delanty G., Odkrywanie Europy. Idea, tożsamość, rzeczywistość, przeł. R. Włodek, WarszawaKraków 1999.

DuCHIŃSKI F., Galeria obrazów polskich. Oddział 1, Różnice ludów indoeuropejskich a turańskich pod względem fizjonomii i odzieży, Paryż 1863.

DuchiŃSKi F., Pisma ..., t. I-III, Rappersvil 1901-1904.

Granice między narodami Aria-Europejskimi i Turano-Moskiewskimi, [b.m.] 1863.

HALECKI O., Historia Europy - jej granice i podziały, przeł. J.M. Kłoczowski, Lublin 2000.

Inglot M., Norwidowska Europa, [w:] Kategoria Europy w kulturach słowiańskich, red. T. DąbekWigrowa, A.Z. Makowiecki, Warszawa 1992.

\footnotetext{
${ }^{42}$ Tamże, nr 10, s. 1 .

${ }^{43}$ C.K. NoRwID, Do Bronistawa Zaleskiego, PWsz IX, 321,

${ }^{44}$ M. INGLOT, Norwidowska Europa, [w:] Kategoria Europy w kulturach słowiańskich,
} red. T. Dąbek-Wigrowa, A.Z. Makowiecki, Warszawa 1992, s. 65. 
ANNA M. DWORAK

Kalendarz życia i twórczości Cypriana Norwida, t. I-III, red. Z. Trojanowiczowa, E. Lijewska, Z. Dambek, Poznań 2007.

KAMIEŃSKi H., Rosja i Europa: Polska, Paryż 1857.

KRASZEWSKI J.I., Moskal. Obrazek wspótczesny, Lipsk 1865.

Kraszewski J.I., Rachunki: (pt.1-2). z roku 1867 (rok drugi), Poznań 1868.

Michna W., Pogląd na wschodnia Europę i Azja i wyjaśnienie stosunków, jakie miata Moskwa z ludami stawiańskiemi od pierwocia bytu do czasów naszych, Przemyśl 1864.

NoRwID C.K., Pisma wszystkie, zebrał, tekst ustalił, wstępem i uwagami krytycznymi opatrzył J.W. Gomulicki, t. I-XI, Warszawa 1971-1976.

Pietrusiński L., Podróże, przejażḋki i przechadzki po Europie, t. I, Warszawa 1843.

Pol W., Historyczny obszar Polski, [w:] TENŻE, Dzieła proza, t. V, Lwów 1878.

Władystaw Ludwik Anczyc: życie i pisma, oprac. M. Szyjkowski, t. II: Wiersze i poemata; Kraków 1909.

Zbiór poetów polskich XIX w., ułożył i oprac. P. Hertz, Księga druga, Warszawa 1959.

\title{
ROSJA: AZJA CZY EUROPA? \\ ROZWAŻANIA O ŚWIADOMOŚCI INTELIGENCJI POLSKIEJ XIX WIEKU JAKO KONTEKŚCIE IDEOWYM TWÓRCZOŚCI CYPRIANA NORWIDA
}

\author{
S t r e s z c z e n i e
}

Przedmiotem artykułu jest omówienie poglądów polskiej inteligencji współczesnej Cyprianowi Norwidowi na kwestię przynależności Rosji do Europy. Wśród omawianych przykładów szczególnie często pojawiają się próby wyrzucenia Rosji poza obręb Europy poprzez podkreślanie jej azjatyckości. Rzadziej można spotkać przykłady myśli panslawistycznej. Poglądy Norwida na kwestię przynależności Azji wydają się na tym tle niezwykle zrównoważone. Poeta dostrzegał odmienność Rosji, jednak uważał, że jej izolowanie od Europy może przynieść więcej strat niż korzyści.

Słowa kluczowe: Rosja; Europa; Azja; świadomość europejska; panslawizm; granice Europy; Słowianie. 


\title{
RUSSIA: ASIA OR EUROPE? \\ REFLECTIONS ON THE AWARENESS OF THE POLISH INTELLIGENTSIA IN THE $19^{\mathrm{TH}}$ CENTURY AS THE IDEOLOGICAL CONTEXT OF NORWID'S WORK
}

\author{
S u m m a r y
}

The article discusses the views of the Polish intelligentsia in Cyprian Norwid's lifetime on the issue of Russia's membership in Europe. Among the discussed examples there are particularly frequent attempts to push Russia out of Europe by emphasising its Asian character. The examples of pan-Slavic ideas are less frequent. Against this background, Norwid's views on the question of Russia's Asianness seem to be exceptionally balanced. The poet noticed that Russia was different, but he believed that isolating it from Europe could be more detrimental than beneficial.

Key words: Russia; Europe; European awareness; pan-Slavism; boundaries of Europe; Slavs.

Translated by Rafat Augustyn

ANNA W. DWORAK - doktor; e-mail: annadworak17@interia.pl 